\title{
ラット障害肝中の肝細胞増殖抑制因子の検討
}

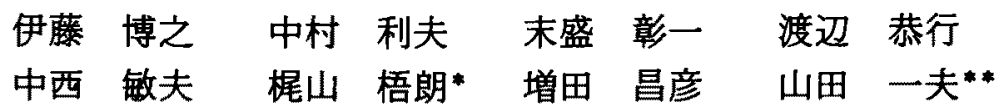

肝細胞增殖因子に関しては最近 HGF 等が分離精 製1され広範な知見が得られている。しかしながら，增 殖抑制因子に関しては比較的報告が少なく $\mathrm{TGF} \beta$ 等 が肝細胞增殖抑制を行うことが報告されているに過ぎ な(2). その他に正常肝, 部分肝切除後の肝满から抽出 された増殖抑制因子の報告はあるが3)，障害肝から抽 出された增殖抑制因子の報告はない，今回我々は障害 肝中の肝細胞增殖因子（仮称：Hepatocyte proliferation inhibitory factor=HPIF）を部分精製後，諸性質 の検討を行い興味ある結果を得たので報告する.

方法：1）肝抽出物質の作成法：ウィスター系雄性 ラット（200g）にD-ガラクトサミン塩酸塩1,500m/

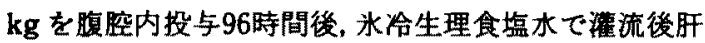
臓を摘出した，摘出した肝荿より Roberts らの方法“ に準して酸ェタノール法により酸可溶性タンパを抽 出し，肝抽出物質とした。 また無処置ラットからも同 様に肝抽出物質を作成した，2）HPIF の部分精製法： PBS K溶解した障害肝，正常肝抽出物質 $4.3 \mathrm{mg}$ を七 ファクリルS300カラム $(1 \times 12 \mathrm{~cm})$ にかけ, PBSで 容出した $(0.5 \mathrm{ml} /$ 分画). 各分画に関して肝細胞增殖抑 制活性を倹討した。 また，肝細胞増殖抑制活性を認め ろ分画に関して形質転換作用の有無を，NRK 49F 細 胞を使用したコロニー形成能で検討した5!．3）肝細胞 堌殖抑制活性の測定法：ラット肝細胞は体重200g 前 後のウィスター系雄性ラットからコラゲナーゼ灌流法 により分離した。分離肝細胞は40mM タルタミン, 100 $\mathrm{U} / \mathrm{m} l$ ベニシリン, $100 \mu \mathrm{g} / \mathrm{m} l$ ストレブトマイシン,

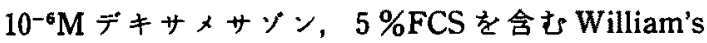
medium Eを用いて $2 \times 10^{5} / \mathrm{m} l$ に調整し， $35 \mathrm{~mm}$ col-

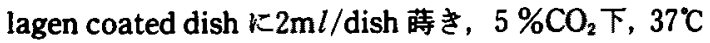
で培養を行った，分嚾培養開始 5 時間後，無血清培地 に変更した，培羡開始24時間後インスリン $\left(10^{-7} \mathrm{M}\right)+$ $\mathrm{EGF}(20 \mathrm{ng} / \mathrm{m} l)$ を含んた無血清培地に变更し，同時 に各分画 $200 \mu l$ を添加した. 更に24時間培養して，ラッ

- 広島大学部第 1 内科

**同 第 1 生化学

〈受付日1990年 5 月30日 $>$
卜肝細胞 DNA 合成能に及ぼす影篅を $\left[{ }^{3} \mathrm{H}\right]$ チミシン $(0.4 \mu \mathrm{Ci} / \mathrm{m} l)$ の DNA への取り込みで測定した。肝細 胞增殖抑制活性 $(\%)=(\mathrm{EGF}$, インスリン添加時の DNA 合成能-EGF，インスリン，各分画添加時の DNA 合成能)/(EGF，インスリン添加時の DNA 合成 能一無添加時の DNA 合成能) $\times 100$ とした。 また, 肝細 胞障害の検討のために培地中 LDH の測定と, 生着細 胞数の検討を行った。生着細胞数の検討は TCA 処理 後の酸不容性画分の蛋白量をLowry 法で測定するこ とで行った。

結果：HPIF の部分精製；肝細胞増殖抑制活性は高 分子分画 (Peak1) と分子量約15,000の分画 (Peak 2) に認められた (Fig. 1). 高分子分画におい、ては培地中 LDH が上䄯し，生着細胞数が隇少していることから， 高分子分画の肝細胞増殖抑制活性は非特異的な肝細胞 障害によると思われる (Fig. 2)。 る5一つ肝細胞增殖

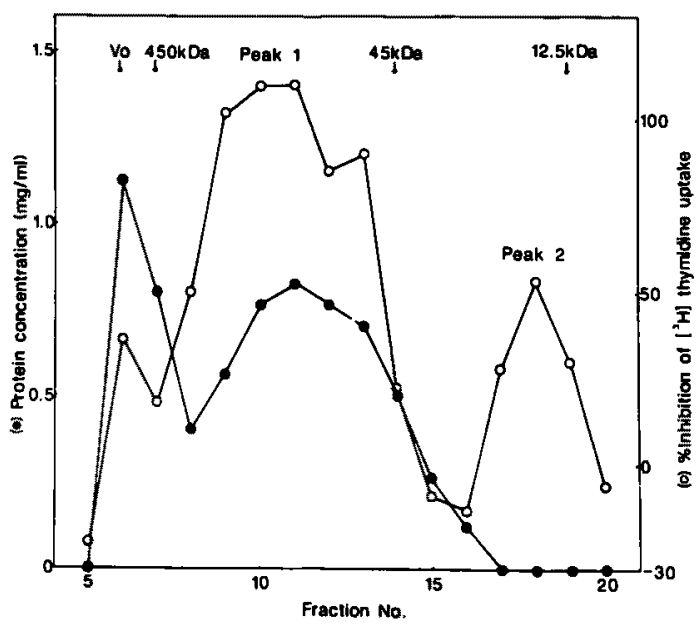

Fig. 1 Sephacryl S300 Chromatogram of liver extracts of rats treated with D-galactosamine. Protein concentration and \%Inhibition of $\left[{ }^{3} \mathrm{H}\right]$ thymidine incorporation were assayed. The following markers for molecular weight were used : ferritin (450kDa), egg albumin $(45 \mathrm{kDa})$ and cyto. chrome $\mathrm{C}(12.5 \mathrm{kDa})$. 


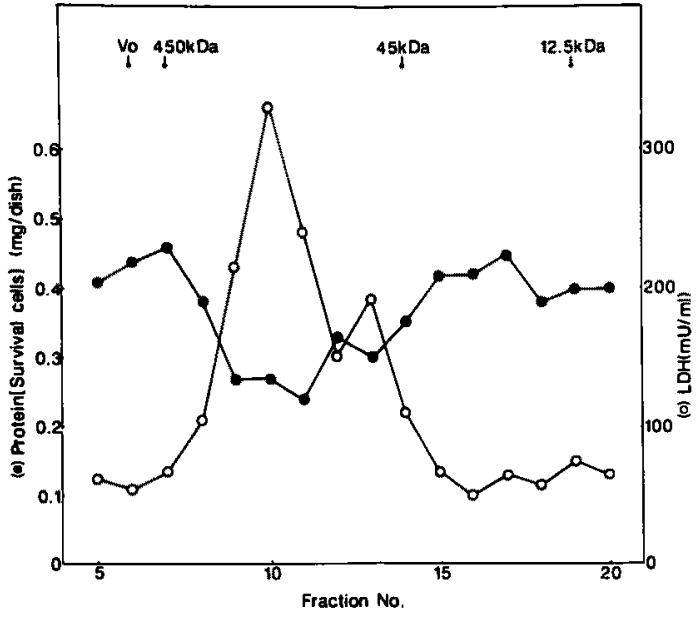

Fig. 2 Sephacryl S300 Chromatogram of liver extracts of rats treated with D-galactosamine. Survival cells and LDH in medium were assayed.

抑制活性を認める分子量的 15,000 の分画においては培 地中 LDH の上昇は認められず，この分画を HPIF と した(Fig. 2)。また，HPIFはコロニー形成能はなく， 形質䎐換作用は認められなかった。 以上の様に障害肝 では分子量約15,000の分画に肝細胞增殖抑制能 (HPIF) が認められるが (Fig. 1)，正常肝には HPIF の発現は認められなかった。
考察：従来より, 正常肝, 部分肝切除後の肝瀻加占 の肝細胞增殖因子の分離が諸家によって試みられてき

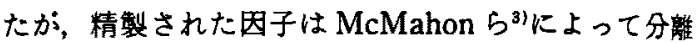
精製された HPI (hepatic proliferation inhibitor)の みである。京た，最近 TGF $\beta$ は肝細胞増殖抑制活性で 注目されており，部分肝切除後に TGF $\beta$ の mRNA の 発現到することが報告されている。

我々が部分精製した HPIFは正常肝には認められ ず，障害肝にのみ認められるが，HPIは正常肝から精

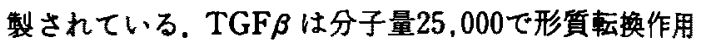
を有しているが, HPIF は形質転作用がなく、より低 分子である。以上ょり，HPIF は HPI 等既知の肝細胞 増殖抑制因子とは異なる可能性が高く，現在更に精製 を進めている。

来引用語：增殖抑制因子，初代培養肝細胞，D-ガラ クトサミン肝障害

文辣：1) Nakamura Toshikazu, et al: Proc Natl Acad Sci USA $83: 6489-6493,1986$ 2) Nakamura Toshikazu, et al: Biochem Biophys Res Commun 133: 1042-1050, 1985 3) McMahon J B, et al: Proc Natl Acad Sci USA 79: 456-460, 1982 4) Roberts AB, et al: Proc Acad Sci USA $77: 3494$ -3498, 1980 5) De Larco J E, et al: Proc Natl Acad Sci USA $75: 4001-4005,1978$ 6) Braun L, et al: Proc Natl Acad Sci USA 85 : 1539-1543, 1988

\section{Heptocyte proliferation inhibitory factor in liver extracts of rats treated with D-Galactosamine}

Hiroyuki Ito, Toshio Nakamura, Shouichi Suemori, Yasuyuki Watanabe, Toshio Nakanishi, Goro KaJTYAMA*, Masahiko Masuda and Kazuo YaMadA**

\footnotetext{
* First Department of Internal Medicine, Hiroshima University School of Medicine (Hiroshima)
}

** First Department of Biochemistry, Hirohima University School of Medicine (Hiroshima) 